Finanse, Rynki Finansowe, Ubezpieczenia nr 4/2016 (82), cz. 2

\title{
A Comparative Analysis of the Innovativeness of Polish Industry from 2008-2014
}

\author{
Waldemar Gajda*
}

\begin{abstract}
Purpose - The main aim of this study is a comparison and assessment of chosen aspects of the innovativeness of the Polish industrial enterprises from 2008-2014.

Design/methodology/approach - A method of comparative analysis was used as a research method in order to pursue the adopted aim.

Findings - Using direct indicators which are based on the results of product, process, organisational and marketing innovations, the comparison of innovative activity of the Polish industrial sector from 2008-2014 taking into consideration small, medium-size and large enterprises was made. Also expenditures on innovative activity in the industrial enterprises and revenues on the sales of new or visibly improved products launched into the market in the years 2008-2014 were analysed. The final part includes an assessment of the innovativeness of Polish industry in the analysed dimensions.

Originality/value - Factual and scientific value of the study concerns: diagnosis of the condition of the innovative activity of Polish industry. It indicates basic shortcomings in the analysed areas.
\end{abstract}

Keywords: analysis, innovativeness, industry, indicators of innovativeness

\section{Introduction}

In the era of the progressive growth of globalisation and high competitiveness innovations are considered as the main cornerstone, a priority instrument of functioning and development of economic entities, sectors as well as the whole economy. On the current stage of civilizational development innovative activity is a driving force with a lofty aim, i.e. development of human beings, the embodiment of values around which leaders may unify people in the common operation for the creation of modern industrial politics based on knowledge, innovativeness and entrepreneurship.

Chosen aspects of the innovative activity of Polish industry constitute the leitmotif of the article. The main aim of the study is to compare and assess the innovativeness of Polish enterprises from 2008-2014.

The method of comparative analysis was used as a research method in order to pursue the adopted aim.

\footnotetext{
* dr inż. Waldemar Gajda, Warszawska Szkoła Zarządzania - Szkoła Wyższa w Warszawie, e-mail: waldgaj@vp.pl.
} 
In the article, the comparison of the innovative activity of Polish industry from 20082014 was made using direct indicators being based on the results of product, process, organisational and marketing innovations. Also, the expenditures on innovative activity in the industrial enterprises and revenues on sales of new or visibly improved products launched into the market during 2008-2014 were analysed. The final part includes an assessment of the innovativeness of Polish industry in the analysed aspects.

\section{Innovative activity of Polish industry from 2008-2014 - a comparative analysis}

Innovative activity includes all actions of a scientific, analytical, technical, organisational, financial and commercial nature aiming at the development of new or visibly improved products and processes and their implementation into economic practice. The implementation of innovations means in particular the introduction of a new technique and technology to produce new products as well as new solutions in managing the enterprise which were not used before (Szewczak 2014, p. 213).

Except for actions connected with the implementation of innovations, research into innovations is a very important aspect supporting the above-mentioned processes. Specified monitors constitute implementing tools. Two main groups of indicators used to measure innovative activity, direct and indirect ones were used in practice.

The indirect indicators specify the value of expenditures and the effects obtained regarding Research and Development Activity (R\&D). They measure the results of the inventive activeness and the conclusions concerning the innovativeness of a given economy are drawn on their basis. These are substitute indicators based on the positive relationship between the level of spending on R\&D as well as the productivity and profitability of the business entities (Godin 2004, pp. 121-122). These indicators are based on the spending on the R\&D, technological intensity, the number of patents as well as patent statistics (Nowak 2012, pp. 154-155).

The GERD indicator is the main unit received as the result of the research into R\&D Activity (Gross Domestic Expenditure on Research and Development). It is specified as gross domestic expenditure on the R\&D activity which involves all expenditure incurred in a given year regardless of the source of it. The GERD constitutes labour costs, other current costs and gross capital expenditure on fixed assets used in R\&D programmes. The GERD indicator has three components: the BERD (Business Expenditures on Research and Development) which is created by the enterprises, the HERD (Higher Education on Research and Development) which is created by education, and the GOVERED (Government Expenditures on Research and Development) which involves government spending (Matusiak 2011, p. 283).

High technology is another indirect measure based on R\&D spending. It involves the fields of production and goods which are characterised by science intensity (the R\&D 
intensity). Two categories of the division of the analyses of high technology are used: the industry approach and the product approach. According to the industry approach, the OECD uses two industry classifications based on R\&D intensity. The older one is recommended in case of analyses devoted to 1970-1980, whereas, the new one, published in 1995, divided the enterprises into four categories:

- high-technology industries - more than 5\% of the R\&D share in turnover,

- medium-high-technology industries $-3-5 \%$ of the R\&D share,

- medium-low technology industries $-1-3 \%$ of the R\&D share,

- low-technology industries $0-1 \%$ of the R\&D share.

The patent indicators are other indirect measures which are based on R\&D Activity. They determine the effects of the patent activity through the number of the patent applications and the number of patents accepted. The procedure of the application of an invention may be conducted in accordance with national and international procedures (Patent Cooperation Treaty).

The other group of measures of innovative activity constitutes the innovativeness indicators based on the Oslo methodology, which is based on the model of the chain link by Rosenberg and Kline of 1986 (Kline, Rosenberg 1986, pp. 275-305). The Oslo methodology introduces four types of innovations: product innovation, process innovation, organisational innovation and marketing innovation. The acceptance of the above-mentioned types of innovations, allows us to classify the Oslo method as subject-oriented which focuses on the innovative activity of enterprises, and not only on the innovations. In this case, innovations are the result of the interactions and constructive feedback in the creation of an economy based on knowledge. In the Oslo methodology, innovative solutions are not treated as an impetus or the mechanism which starts the innovation process but they are their effects (Nowak 2012, p. 157).

Basing on the Oslo methodology this group of direct tools was used in the article to conduct a comparative analysis of the innovative activity of Polish industry during the years 2008-2014.

Table 1 presents a summary of innovative activity of the industrial enterprises taking into account innovative activity regarding product, organisation and marketing.

From 2008-2010, in Poland, 18.1\% of the industrial enterprises (GUS 2011, p. 7) confirmed innovative activity understood as the implementation of at least one product or process innovation or realizing at least one innovative project which was discontinued or abandoned within the studied period or was not terminated till the end of this period (GUS 2013, p. 29).

The following years of 2009-2011 are the only ones in the studied period in which there is a fall of the innovative activity of the enterprises to the level of $16.9 \%$ and it is undoubtedly the result of the global economic crisis of that time (GUS 2012, p. 7).

There is reconstruction of innovative activity within 2010-2012 and its increase to the level of 17.7\% (GUS 2013, p. 7). The following years of 2011-2013 and 2012-2014 were 
connected with the increase by 0.7 and 0.2 percentage points, respectively to the level of $18.6 \%$ and it has been the best result achieved by Polish industry since 2008 (GUS 2014, p. 1).

\section{Table 1}

Innovative activity of the industrial enterprises during the years 2008-2014 (\%)

\begin{tabular}{llllll}
\hline Activities & $2008-2010$ & $2009-2011$ & $2010-2012$ & $2011-2013$ & $2012-2014$ \\
\hline Innovation activities & 18.1 & 16.9 & 17.7 & 18.4 & 18.6 \\
Product innovations & 12.1 & 11.2 & 11.2 & 11.0 & 11.7 \\
Process innovations & 12.9 & 12.4 & 12.4 & 12.8 & 12.9 \\
Organizational innovations & 13.0 & 8.3 & 10.3 & 8.3 & 8.4 \\
Marketing innovations & 13.5 & 7.9 & 10.2 & 7.5 & 7.6 \\
\hline
\end{tabular}

Source: own elaboration on the basis of GUS data (Główny Urząd Statystyczny).

Conducting an analysis of particular types of innovations, i.e. product, process, organisational and marketing ones in the specific periods one should indicate that:

1. The highest percent of the industrial enterprises which introduced product innovations was during 2008-2010 when it was over 12\%. In the remaining studied period it was from $11.0 \%$ to $11.7 \%$ (GUS 2015, p. 1). In order to say that the enterprise was innovative in the scope of a product it had to launch into the market at least one product which was new or visibly improved as far as its features or usages are concerned and in this aspect one may conclude that there is a slow increase of innovativeness in the area of product.

2. Innovations in the methods of producing products $(10 \%)$; methods supporting processes in the enterprise (6.4\%) as well as logistics methods and/or delivery and distribution methods (3.3\%) (GUS 2011, p. 29) were the most often implemented process innovations in the industrial enterprises in 2008-2010. The hierarchy of methods did not change in the following years 2010-2012 and 2012-2014. However, there was a slight change of the percent of the enterprises implementing innovations. New or visibly improved methods of production of products within 2010-2012 were introduced by $9.7 \%$ of all industrial enterprises whereas it was $10 \%$ during 2012-2014; new or visibly improved methods supporting processes in 2010-2012 were introduced by $5.4 \%$ of the industrial enterprises and from 2012-2014 this percentage constituted $5.6 \%$. New or visibly improved methods from logistics and distributions were implemented by $3.0 \%$ of enterprises in 2010-2012 and 3.0\% in 2012-2014 (GUS 2013, p. 42; GUS 2015, p. 1).

3. As far as organisational innovations are concerned, new methods in the scope of principles of operation accepted by the industrial enterprises were implemented the most often during 2008-2010 (9.0\%). Whereas in 2010-2012 these were new business practices for organising (7.3\%); new methods of organising work responsibilities 
and decision making (6.7\%) and new methods of organising external relations (3.8\%) (GUS 2013, p. 53). The latest research regarding 2012-2014 shows that organisational innovations which are implemented the most frequently include new methods in the principles of operation (6.2\%); new methods of the division of tasks and decisionmaking powers $(5.7 \%)$ and new organisational methods in the matter of relationships with the surrounding environment (3.5\%) (GUS 2015, p. 2).

4. As regards marketing innovations in the industrial enterprises from 2008-2010, the biggest number of enterprises implemented changes in the new methods of pricing goods or services $(8.0 \%)$; in the new media or techniques for product promotion $(6.6 \%)$; as well as in the significant changes to the aesthetic design or packaging of goods (5.4\%) (GUS 2011, p. 39). There was a percentage decline in the number of enterprises implementing innovative changes in all of the above-analysed areas during 2010-2012 and it was 5.2\% for each area (GUS 2013, p. 59). From 2012-2014 there was not only a change in the hierarchy but also another drop in the percentage in the analysed areas, namely in the significant changes to the aesthetic design or packaging of a good to the level of $4.4 \%$; in the new media or techniques for product promotion to the level of $3.9 \%$ and in the new methods of pricing goods or services to the level of $3.6 \%$ (GUS 2015, p. 2).

The structure of companies implementing innovations is a significant aspect impinging on the innovative activity of the Polish industrial enterprises. During 2008-2010, 70.9\% of the industrial enterprises employed from 10 to 49 workers and their innovative activity was of $10.4 \%$. Whereas large companies hiring over 499 workers constituting $2.0 \%$ of the whole number of the industrial enterprises indicated innovative activity of $69.6 \%$ (GUS 2011, p. 16, 19). In 2010-2012, the percentage of innovative activity of the companies hiring up to 49 workers did not change and was at $10.4 \%$ to $71.9 \%$. While large companies with over 250 employees constituting at that time $5.0 \%$ of the total number of the industrial enterprises indicated innovative activity at 59.3\% (GUS 2013, pp. 23, 30). There was a decrease of innovative activity during 2012-2014 both in small and large enterprises. The enterprises employing from 10 to 49 workers had innovative activity in the scope of product innovations of $6.9 \%$ whereas the companies hiring over 250 workers showed the activity at $43.8 \%$. Innovative activity for the process innovations was of $7.9 \%$ in the case of companies employing up to 49 workers and $45.0 \%$ among the companies employing over 250 workers. Organisational innovations constituted $5.4 \%$ and $35.38 \%$, respectively and marketing ones $5.4 \%$ and $27.1 \%$ for the benefit of large companies (GUS 2015, p. 2).

The groups of industry which focused the biggest percentage of innovative enterprises were another aspect. From 2008-2010, the highest percentage of innovative companies among the industrial enterprises belonged to the group Manufacturing basic pharmaceutical substances as well as medicines and other pharmaceutical preparations. $53.1 \%$ of these enterprises were innovatively active; Manufacture of tobacco products with the activity at $46.2 \%$ as well as the Manufacture of coke and refined petroleum products (40.4\%) (GUS 
2011, p. 24). In 2010-2012, the highest percentage of the industrial enterprises which were innovatively active in the group Manufacture of coke and refined petroleum products, in which there were $52.3 \%$ of the enterprises which were innovatively active; mining of coal and lignite with activity at the level of $47.8 \%$ as well as the Manufacture of pharmaceutical products (47.2\%) (GUS 2013, p. 31). Whereas from 2012-2014 there was the biggest participation of the enterprises implementing innovations took place again in the following groups: Manufacture of basic pharmaceutical substances as well as medicines and other pharmaceutical preparations (45.6\%) as well as the Manufacture of chemicals and chemical products (38.9\%) (GUS 2015, p. 2).

\section{The analysis of expenditures on innovative activity in the industrial enterprises during 2008-2014}

Figure 1 presents the statement of expenditures on innovative activity during 2008-2014 in the industrial enterprises.

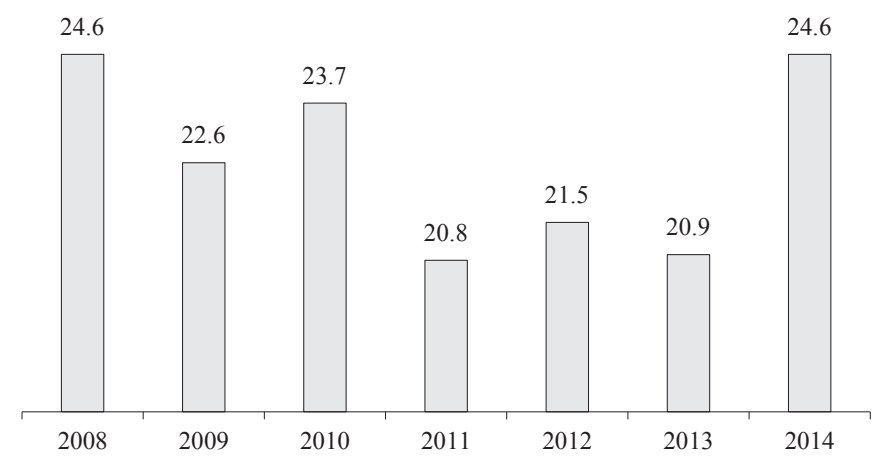

Figure 1. Expenditures on innovative activity in the industrial enterprises within 2008-2014 (mld PLN)

Source: own elaboration on the basis of GUS data.

The analysed data suggests that expenditures on innovative activity in the industrial enterprises had their highest rate in 2008 and 2014 and the sum constituted PLN 24.6 billion.

In 2009 , there was a $8.2 \%$ decline in the expenditures in the group of industrial enterprises to the level of PLN 22.6 billion. In 2008 and 2009, the majority of expenditures in innovative activity were incurred by the enterprises from the private sector. In 2008, in this sector expenditures on innovative activity constituted $78.3 \%$ of all expenditures on innovative activity, whereas in 2009, it was $70.6 \%$ (GUS 2010, p. 19).

In 2010, there was increase of expenditures on innovations in the industrial enterprises to the level of PLN 23.7 billion. Own funds of enterprises constituted $75.2 \%$ of all expenditures 
incurred in the industry in this aim and were the main source of financing expenditures on innovative activity in 2010 (GUS 2011, p. 8).

In 2011, expenditures on innovative activity in absolute terms reached PLN 20.8 billion and it was the worst result in the analysed period. Own funds of enterprises were again the main source of financing the expenditures in innovative activity and constituted nearly three quarters of all expenditures incurred in this aim.

In 2012 the industrial enterprises spent PLN 21.5 billion on innovations. Similarly as in 2011 and 2010, the greatest sum was spent on the purchase of machines and technical equipment, means of transport, tools, instruments, movables and equipment. These expenditures accounted for $58.2 \%$ (in comparison with $59.2 \%$ in 2011) of all expenditures on innovative activity in the industrial enterprises. In 2011, the lowest expenditures on innovative activity in industry were incurred on staff training connected directly with the implementation of process or product innovations. Own funds constituted the main source of financing expenditures in innovative activity in 2012. Like in 2011, they accounted for almost three quarters of all expenditures in the industrial enterprises incurred in that aim (GUS 2013, p. 8).

PLN 20.9 billion was the sum spent on innovative activity in 2013 and these are one of the lowest expenditures within the whole analysed period. In the industrial enterprises the greatest part of funds was spent on investments $-73.6 \%$ of total expenditures on innovations. Expenditures on innovative activity in industry were mainly financed from own resources of enterprises (71.1\%) (GUS 2014, p. 4).

The latest data indicates that expenditures in innovative activity in 2014 in the industrial enterprises increased by PLN 3.7 billion in relation to the previous year and they accounted for PLN 24.6 billion. It is the best result in the analysed period. Similarly as in 2013 investment expenditures dominated and they constituted $75.3 \%$ of total expenditures on innovations. Expenditures on innovative activity in the industrial enterprises came, as previously, mainly from own funds and accounted for 69.2\% (GUS 2015, p. 3).

\section{The analysis of revenues on the sales of new or visibly improved products launched in the market during 2008-2014}

Conducting the analysis of revenues on the sales of new or visibly improved products one should stress that the following revenues from sales are analysed:

- new or visibly improved products on the market in which the enterprise operates,

- new or visibly improved products only for the enterprise.

Figure 2 presents a summary statement of the net revenues of new or visibly improved products within specific periods.

As it may be concluded on the basis of the graph, the share of net revenues on the sales of new or visibly improved products launched into the market during 2008-2010 in total revenues on sales in 2010 was $11.3 \%$ for the industrial enterprises. The greatest share of 
revenues on sales of new or visibly improved products in total revenues appeared in case of the entities which hired more than 499 persons (GUS 2011, p. 8).

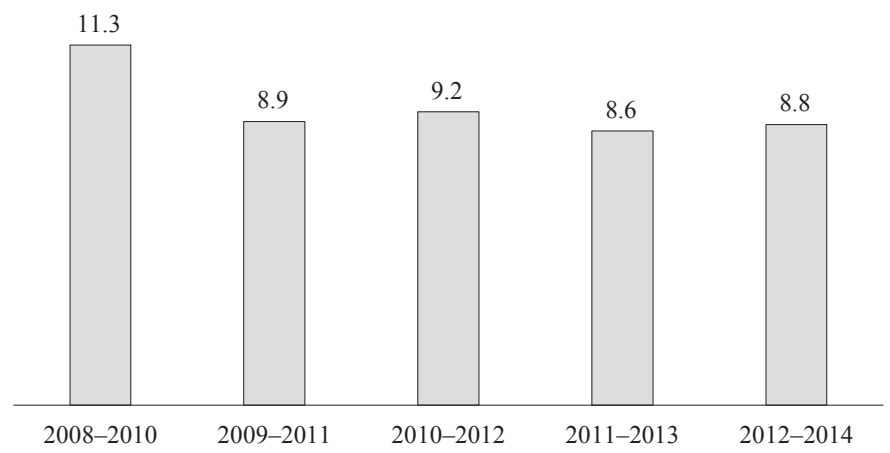

Figure 2. Revenues on sales of new or visibly improved products launched onto the market by the industrial enterprises during 2008-2014 (\%)

Source: own elaboration on the basis of GUS data.

The period of 2009-2011 meant a decline by 2.4 percentage points to the level of $8.9 \%$ and this level could be observed with small variations till 2014.

Within 2010-2012 the share of net revenues on sales of new or visibly improved products launched into the market in total revenues in 2012 was $9.2 \%$ (it was 0.3 percentage points more than during 2009-2011). Similarly as in previous years the greatest share from revenues on the sales of new or visibly improved products in total revenues was achieved by the entities which employed 250 persons and more (GUS 2013, p. 8).

There was a decline and the lowest level of share of net revenues on the sales of new or visibly improved products launched into the market in the industrial enterprises with the level of 8.6\% from 2011-2013.

The latest data of 2014 indicate a small, by 0.2 percentage point, increase of the shares of revenues on sales of new or visibly improved products in relation to the lowest value in 2013. This tendency is maintained below $9 \%$. Moreover, the principle that the greatest revenues in the industry are generated by the enterprises hiring 250 persons and more is proved (GUS 2015, p. 3).

\section{The assessment and conclusions concerning innovativeness of Polish industry in the analysed dimension}

Innovative activity of the Polish industrial enterprises within 2008-2014 was at a low level. Only $16.9-18.6 \%$ of the enterprises in the whole industry showed innovative activity. The activity which in the approved criterion (reasonable one) relies on implementing during 
the analysed period at least one product or process innovation or realizing at least one innovative project which was discontinued or abandoned during the analysed period (did not end successfully) or was not terminated till the end of this period (it has been continued). One should observe a positive tendency, i.e. there has been a slow and systematic growth of innovative activity of Polish industrial enterprises since 2009-2011 when there was the lowest level of innovative activity in the industry connected undoubtedly with the global economic crisis.

In comparison with the period of 2008-2010 in case of particular types of products, process, organisational and marketing innovations there was a decline in product innovations from $12.1 \%$ to $11.7 \%$ during $2012-2014$; in the case of process innovations their level was the same, i.e. $12.1 \%$; there was a significant drop from $13.0 \%$ to $8.4 \%$ as regards organisational innovations and the most visible decline in the case of marketing innovations - by 5.9 percentage points from $13.5 \%$ to $7.6 \%$. From a scientific point of view, there are many reasons for such a situation. The most basic and most important one is the elimination of barriers for innovativeness. Such barriers lead, except for blocking the implementation of innovations, to impairing or withholding implementation of the process which took place in the enterprise before (Szopik-Depczyńska 2014, p. 490).

The conducted analysis of innovative activity indicated a very unfavourable trend in the structure of companies which aspire to be innovatively active. The industrial enterprises which employ from 10 to 49 workers constituting almost $71 \%$ of all enterprises in the industry during 2008-2010 and 2010-2012 had innovative activity at the level of only $10.4 \%$. Whereas the enterprises hiring more than 499 workers from 2008-2010 showed innovative activity at the level of nearly $70 \%$ having $2 \%$ of the share in the market. The following years brought a decreasing trend of innovative activity both among small enterprises with up to 49 workers and large companies employing more than 250 workers. The actions which aim at reversing decreasing trends in innovative activity and first of all, increasing the innovative activity of small companies which have over $70 \%$ of share in the market are necessary.

The groups of industry which focused the highest percentage of innovative enterprises from 2008 to 2014 are practically unchanged and they involve: Manufacture of pharmaceutical products; Manufacture of coke and refined petroleum products; Manufacture of chemicals and chemical products; Mining of coal and lignite. Such a position of the groups of the industry in which innovative activity is the greatest confirms the conclusion from the analysis with regards to the structuring of companies. In these groups of industry one may find large companies which employ over 250 workers and they are the most innovatively active.

The conducted analysis of the expenditures on innovative activity in Polish industry as well as revenues on the sales of new or visibly improved products launched into the market indicates that the expenditures are not transferred into the economic effects in the form of net revenues on the sales of innovative products. The lack of such a transfer is perfectly presented in the case of the situation of 2014. The increase of the expenditures on innovations in 2014 by PLN 3.7 billion, i.e. by 15\% caused the increase of net revenues on sales of new or 
visibly improved products launched into the market by 0.2 of a percentage point from $8.6 \%$ to $8.8 \%$. A similar situation refers to the total analysed period.

\section{Conclusions}

It is undeniable that the innovativeness of industrial enterprises is one of the foundations and a key to the creation of competitive advantage as a solid basis of the sustainable growth. Implementing new, visibly improved products, processes and methods is necessary to prosper in a contemporary and very competitive market. Nowadays growth based only on price competition is not a guaranty of success. It is technological progress which is a priority, sine the qua non ensuring growth of industry and the one which perpetuates the economic growth.

Therefore, scientific research as well as the conducted analyses of the innovative activity of the industrial enterprises should constitute a basis in diagnosing the situation and lead to adequate changes.

Summing up the data presented in the article, one should indicate that the level of innovativeness of the Polish industrial enterprises is not high. This level is proved by the annual report concerning innovativeness among the EU states which has been published since 2001. The report takes into consideration 25 indicators in 8 dimensions of innovativeness. A synthetic indicator of innovativeness of particular states of the EU is calculated on the basis of the above-mentioned indicators. In 2015, Poland with the indicator of 0.313 has the fifth position from the end (European Union 2015).

Taking into account that Poland is considered as the $23^{\text {rd }}$ economy of the world with the tendency to be promoted to the group of the biggest economies in 2023, the results of the carried out analyses as well as presented rankings show how much we have to do in the matter of innovations to catch up with other Member States.

One should remember that the current economic growth of Poland is based on low labour costs, domestic market and union funds. Nevertheless, these simple reservoirs of growth will run out and Poland may face the problem of the lack of opportunity of further growth. Therefore, the development of Polish innovativeness and actions aiming at the elimination of the distance between Poland and the leading states of the EU is such an important aspect (Gajda 2015, p. 152).

\section{References}

European Union (2015). Innovation Union Scoreboard 2015. Maastricht Economic and Social Research Institute on Innovation and Technology (UNU-MERIT), Maastricht.

Gajda W. (2015). Enterprises in unstable economy, w: Enterprises in unstable economy, B. Prusak (ed.), Gdańsk: Gdańsk University of Technology.

Godin B. (2004). Obsession for Competivness and its Impact on Statistics: the Constraction of High Technology Indicators. Research Policy, 33, 121-122. 
GUS (2010). Działalność innowacyjna przedsiębiorstw w latach 2006-2009. Warszawa: Główny Urząd Statystyczny. GUS (2011). Działalność innowacyjna przedsiębiorstw w latach 2008-2010. Warszawa: Główny Urząd Statystyczny. GUS (2012). Działalność innowacyjna przedsiębiorstw w latach 2009-2011. Warszawa: Główny Urząd Statystyczny. GUS (2013). Działalność innowacyjna przedsiębiorstw w latach 2010-2012. Warszawa: Główny Urząd Statystyczny. GUS (2014). Działalność innowacyjna w Polsce. Szczecin: Urząd Statystyczny w Szczecinie.

GUS (2015). Działalność innowacyjna w Polsce. Szczecin: Urząd Statystyczny w Szczecinie.

Kline S.J., Rosenberg N. (1986). An overview of innovation. In: R. Landau, N. Rosenberg (eds.), The Positive Sun Strategy: Harnessing Technology for Economic Growth (pp. 275-305). Washington D.C.: National Academy Press.

Nowak P. (2012). Poziom innowacyjności polskiej gospodarki na tle krajów UE. Prace Komisji Geografii Przemysłu nr 19. Warszawa-Kraków.

OECD, Eurostat (2008). Podręcznik Oslo. Zasady gromadzenia i interpretacji danych dotyczacych innowacji. Warszawa: Ministerstwo Nauki i Szkolnictwa Wyższego, Departament Strategii i Rozwoju Nauki.

Szewczak K.H. (2013). Zarządzanie eksploatacja środków trwatych w przedsiębiorstwie. Warszawa: Difin.

Szopik-Depczyńska K. (2014). Źródła finansowania projektów w procesie kooperacji a innowacyjność przedsiębiorstw przemysłowych na Pomorzu Zachodnim. Zeszyty Naukowe Uniwersytetu Szczecińskiego nr 803, Finanse, Rynki Finansowe, Ubezpieczenia, 66.

\section{ANALIZA PORÓWNAWCZA INNOWACYJNOŚCI POLSKIEGO PRZEMYSLU W LATACH 2008-2014}

Streszczenie: Cel - Celem głównym opracowania jest porównanie i ocena wybranych aspektów innowacyjności polskich przedsiębiorstw przemysłowych w latach 2008-2014.

Metodologia badania - Dla realizacji przyjętego celu jako metodę badawczą wykorzystano metodę analizy porównawczej.

Wynik - Przy wykorzystaniu wskaźników bezpośrednich bazujących na rezultatach innowacji produktowych, procesowych, organizacyjnych i marketingowych dokonano porównania aktywności innowacyjnej polskiego sektora przemysłowego w latach 2008-2014 z uwzględnieniem małych, średnich i dużych przedsiębiorstw. Analizie poddano również nakłady na działalność innowacyjną w przedsiębiorstwach przemysłowych oraz przychody ze sprzedaży produktów nowych lub istotnie ulepszonych wprowadzonych na rynek w latach 2008-2014. Podsumowaniem jest ocena innowacyjności polskiego przemysłu w analizowanych wymiarach.

Oryginalność/wartość - Wartość merytoryczna i naukowa niniejszego opracowania dotyczy: diagnozy stanu aktywności innowacyjnej polskiego przemysłu: wskazuje podstawowe mankamenty w badanych obszarach.

Słowa kluczowe: analiza, innowacyjność, przemysł, wskaźniki innowacyjności

\section{Citation}

Gajda W. (2016). A comparative analysis of the innovativeness of Polish industry from 2008-2014. Finanse, Rynki Finansowe, Ubezpieczenia, 4 (82/1), 35-45. DOI: 10.18276/frfu.2016.4.82/1-03. 